\title{
The forensic value of smile photograph and medical radiograph analysis in identifying human skeletonized remains: a case report
}

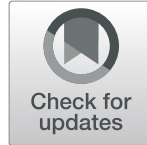

\author{
Majid Ghazi Aljaber Abo Fakher ${ }^{1} \mathbb{B}$, Maher Al-assaf ${ }^{2 *} \mathbb{D}$, Sharif Mimas ${ }^{3} \mathbb{B}$, Mourad Aljaber Abo Fakher ${ }^{4} \mathbb{D}$, \\ Mahmoud Abdul-hak ${ }^{1}$ (D) and Houssein Nofal ${ }^{5}$ (D)
}

\begin{abstract}
Background: Identifying human remains which are skeletonized, carbonized, disfigured, or fragmentized is a common task for forensic anthropologists and odontologists.

Case presentation: A case of unknown skeletonized remains is reported in this investigation, which was found in a mass grave in Damascus Countryside governorate, Syria, in 2017. The post-mortem (PM) examination of bones and teeth was completed in al-Muwasat University Hospital in Damascus. Skull and pelvic bones showed Caucasoid male traits: the fourth rib and teeth examination estimated the age to be between 30 and 40 years, and the long bone estimated the stature in centimeters to be between 172 and 179. Intact dentition with tiny fracture in the incisal edge of the upper right central incisor-along with pathological fracture of right patella - was noted. Matching with ante-mortem (AM) smile photograph and radiograph of the right knee led to positive identification.

Conclusions: The present study highlights the importance of maintaining and storage of medical radiographs or any other records that show the teeth or bones of the person.
\end{abstract}

Keywords: Human remains, Forensic anthropology, Identification, Forensic radiology

\section{Background}

Identifying human skeletal remains having elapsed long time since death poses challenges on and requires a multidisciplinary approach to establishing a positive correlation between the recovered remains and the identity of the dead (Silva et al. 2013). Moreover, forensic odontology and anthropology are highly valuable when traditional methods of identification, such as fingerprints or visual recognition, are unable to be utilized (Franco et al. 2015).

In the case of skeletonized human remains, antemortem (AM) medical records of dental and skeletal trauma or any pathological condition play an extremely valuable role, allowing to compare the findings in postmortem (PM) exams and those AM records. Thus, it is

\footnotetext{
* Correspondence: dr.maher.assaf1990@gmail.com

${ }^{2}$ Department of Oral Histology and Pathology, Faculty of Dentistry, Damascus University, Damascus, Syria

Full list of author information is available at the end of the article
}

imperative that forensic anthropologists and odontologists ask family members for evidence, to seek any type of orthopedic radiographs or smile photographs that show the teeth which contain unique characters of their missing beloved (Dumanèiæ et al. 2001; Kullman 2002; Silva et al. 2013; Terada et al. 2013; Silva et al. 2015; Silva et al. 2016).

This paper reports a positive identification case of a Syrian adult male, achieved by detecting bone and dental fractures and confirmed by comparing these postmortem findings to ante-mortem photograph and radiograph.

\section{Case presentation}

In 2017, a completely skeletonized human remains were found with 52 other skeletons in a mass grave near an uninhabited area in Damascus Countryside governorate, Syria. After crime scene investigation, the bones were

\section{Springer Open}

(๑) The Author(s). 2020 Open Access This article is licensed under a Creative Commons Attribution 4.0 International License, which permits use, sharing, adaptation, distribution and reproduction in any medium or format, as long as you give appropriate credit to the original author(s) and the source, provide a link to the Creative Commons licence, and indicate if changes were made. The images or other third party material in this article are included in the article's Creative Commons licence, unless indicated otherwise in a credit line to the material. If material is not included in the article's Creative Commons licence and your intended use is not permitted by statutory regulation or exceeds the permitted use, you will need to obtain permission directly from the copyright holder. To view a copy of this licence, visit http://creativecommons.org/licenses/by/4.0/. 


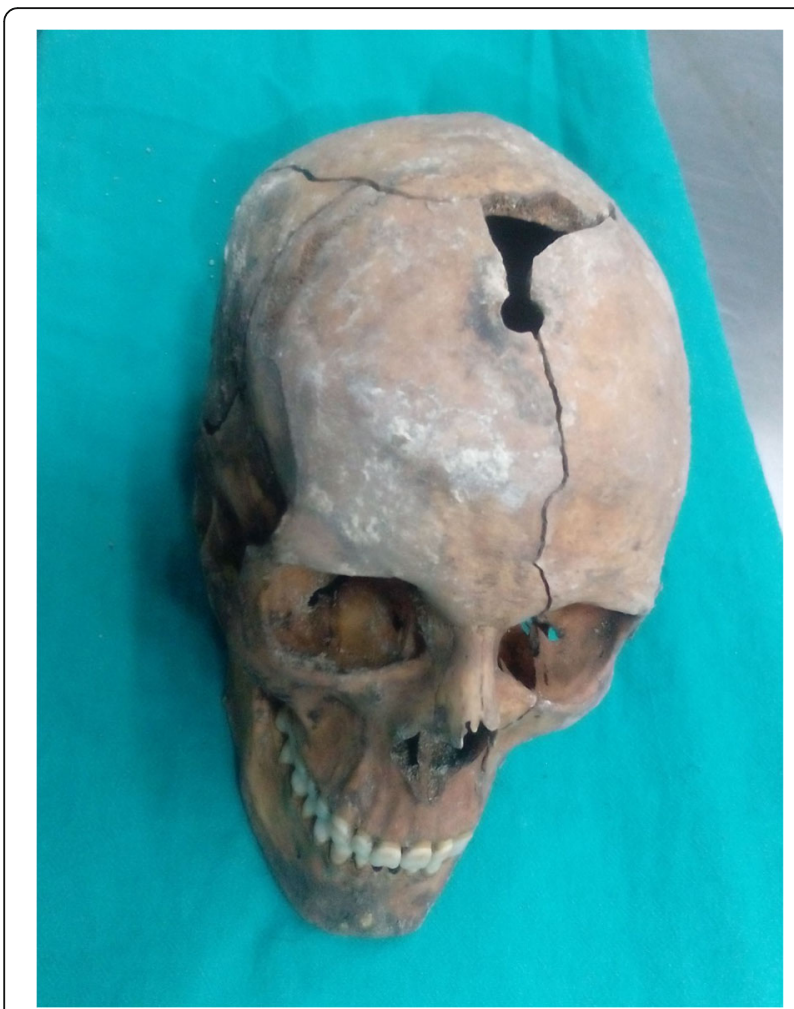

Fig. 1 The gunshot wound on frontal bone and the blackening ring around the entrance hole

referred to the morgue of al-Muwasat University Hospital in Damascus for anthropological and dental identification.

After the bones were cleaned, they were examined solely and carefully. A peri-mortem gunshot wound was found on the squamous of the frontal bone at the midline, and the blackening ring around the entrance hole indicated that the muzzle of the firearm was held in contact with the victim's head (DiMaio 1999) (Fig. 1).
Cranial and pelvic bones indicated male traits and Caucasoid origin (Burns 2013), and the long bones estimated the dead's height to range between $172 \mathrm{~cm}$ and $179 \mathrm{~cm}$ according to Trotter and Gleser (Trotter and Gleser 1952). Besides, the age at death was estimated to be in the fourth decade, depending on Lamendin's method of dental aging (Lamendin et al. 1992) and the shape of sternal end of the fourth rib (Ișcan et al. 1984).

The forensic odontologists noticed that there were two teeth (the lower central incisors) lost PM, and no cavities or restorations were present in the remaining dentition. An AM tiny fracture at the middle of incisal edge in the upper right central incisor caught the investigators' attention for its influence on smile appearance that could be detected through AM photographs.

The examination of the bones exhibited presence of an inflammation in the distal end of the right femur and a pathological fracture in the right patella (Fig. 2), which indicates a previous pathological history for the diseased (Ortner 2003). The right femur, tibia, and patella were placed anatomically and then photographed.

Two weeks later, a man came to the recognition center to inform about his missing brother who was at the age of 34 when he was lost in 2014. He denied any dental history for his brother, yet he mentioned that he suffered from a swelling and pain in his right knee that hindered him from standing and moving. $\mathrm{He}$, furthermore, provided a radiograph for his brother's knee, which was taken 5 years before disappearing. He also provided a photo showing the anterior teeth of the missing man; it revealed a defect in the upper right central incisor that matched exactly what had been found in the examination of the same skeletal remains (Fig. 3). The radiograph also revealed an extreme matching with the photo of the knee found (Fig. 4). This positive correlation between the records and the remains confirmed that these remains belong to the missing person.

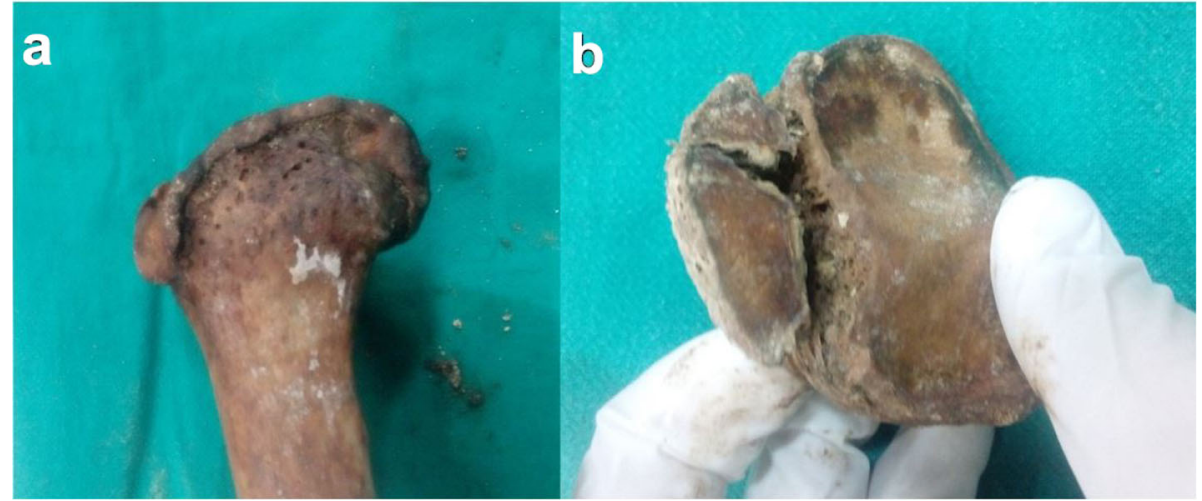

Fig. 2 a The inflammation in distal end of right femur. b The pathological fracture in right patella 


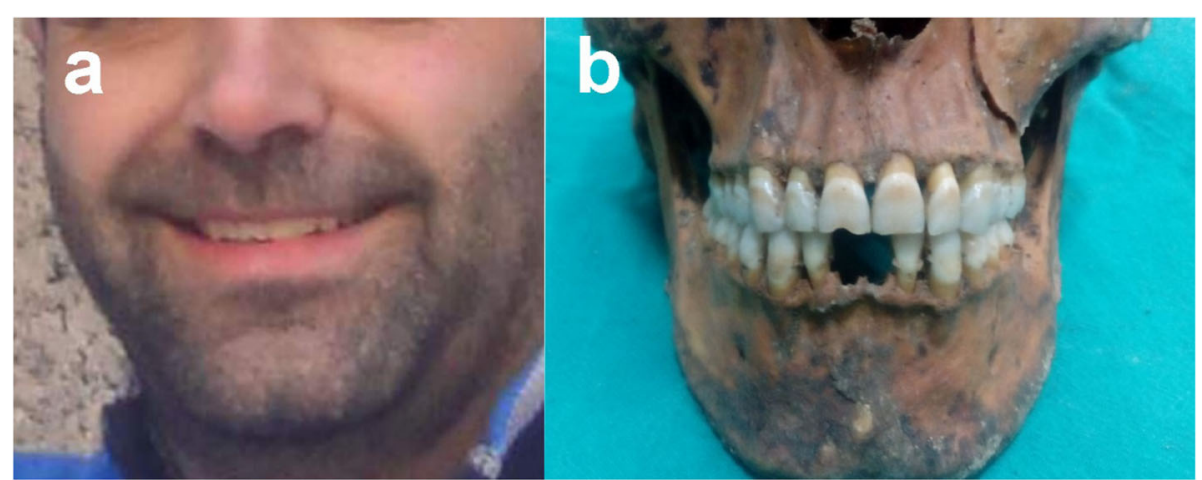

Fig. 3 The tiny fracture at middle of incisal edge in upper right incisor. a Ante-mortem, b post-mortem

This study is legally authorized by the committee of ethics in al-Muwasat University Hospital, and the consent for publication has been taken from the victim's brother (No. 386/2017).

Matching anatomical and patho-morphological features present on AM radiographs and PM examination is an accepted method and considered to be one of the most reliable techniques to get positive identification of human remains (Franco et al. 2015; Silva et al. 2015). Recently, the forensic medical literature highlights the increasing trend of using smile photographs to identify unknown victims (Silva et al. 2008; Terada et al. 2013; Silva et al. 2015; Miranda et al. 2016; Silva et al. 2016). This is ascribed to the development of digital photographic techniques and their cheap cost, rapid speed, and the accessibility to all age groups, especially through mobile phones (Miranda et al. 2016). However, there may exist some drawbacks, such as the low quality of the pictures and the limited number of the teeth that appear in the photograph.

The scientific literature includes several scientific articles (Silva et al. 2008; Tinoco et al. 2010; Terada et al.

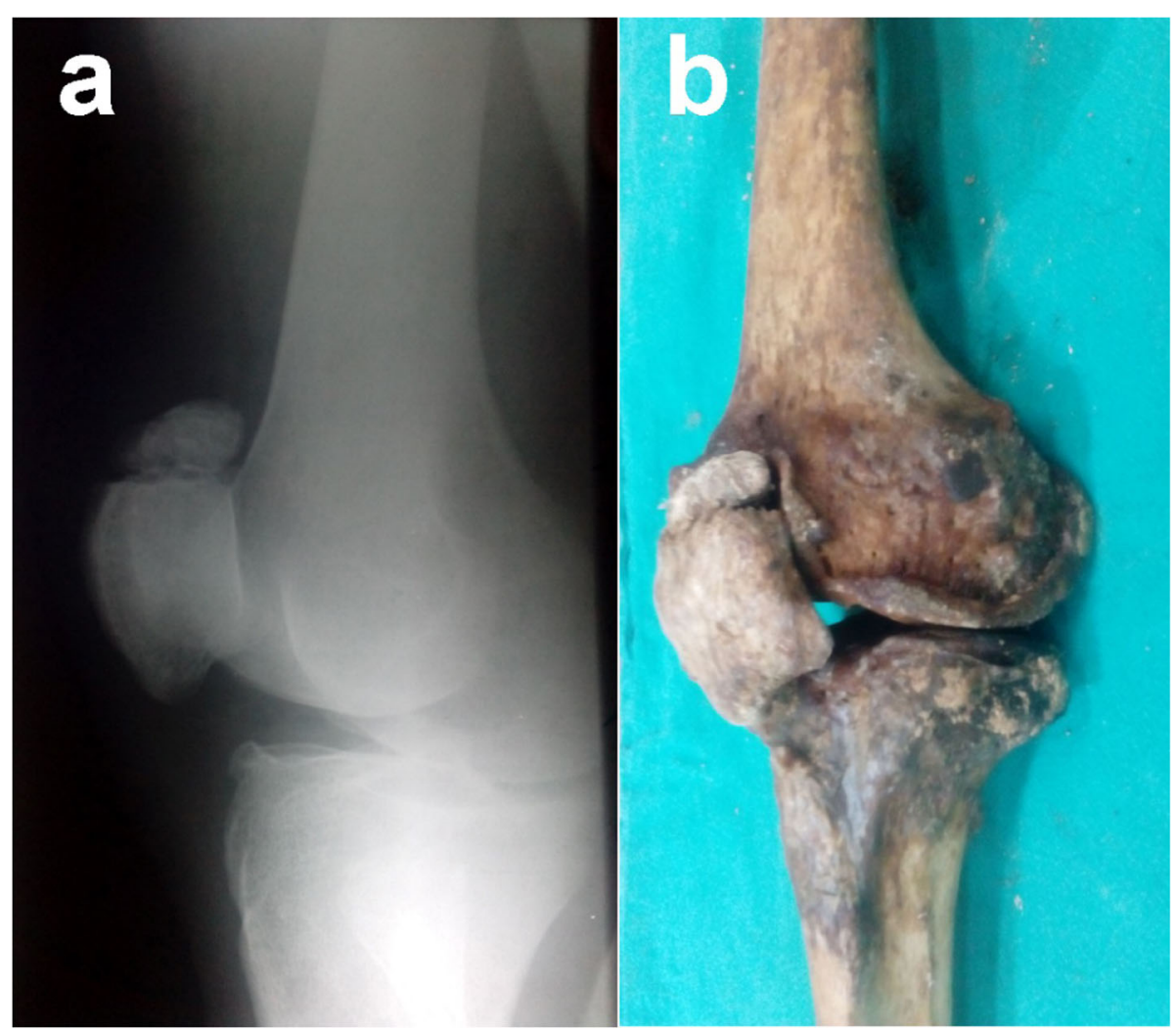

Fig. 4 The match between $\mathbf{a}$ ante-mortem radiograph of right knee and $\mathbf{b}$ post-mortem right knee bones 
2013; Silva et al. 2015; Miranda et al. 2016; Silva et al. 2016) based on the smile to reach the positive recognition. Some depend on the dental anomalies (Tinoco et al. 2010); others depend on the presence of the previous dental treatment in the photo (Silva et al. 2016), while some others depend on the "selfies" taken by the victims that show unique patterns of the anterior teeth in both jaws (Miranda et al. 2016). Nonetheless, a surplus of authors (Dumanèiæ et al. 2001; Silva et al. 2008; Franco et al. 2015) emphasized the importance of the presence of a dentally skilled eye for detecting the considerable dental evidence for the recognition process, which is emphasized here in the current study.

In contrast, few studies in the scientific literature are based on the patella in the recognition process; most of which depended on its morphology (morphological trait). This can be traced in the three patterns of bifid patellae in Ying et al. (Ying et al. 2010), the case of congenital double patella in the study of Fierro et al. ( Fierro et al. 1987), and the distinctive shape of the dorsal surface of patella in Riddick et al. ( Riddick et al. 1983).

Ma et al. (Ma et al. 2017) stressed on the significance of distinguishing between bipartite patella and patella fracture in the forensic context. Silva et al. (Silva et al. 2014) also reported two cases of positive identification in which surgical interventions and morphological traits of patellae were beneficial in the forensic anthropological investigation.

The studied human remains in this study had no specific sign except for a tiny dental fracture and a pathological fracture in the right patella. All teeth were unfortunately intact, which means the lack of AM dental records; in addition, these remains were in a mass grave that included over than 50 others.

Dealing with a great number of human remains in circumstances of mass disasters and mass graves, especially in a country suffering from armed conflict, like Syria, makes the forensic expertise lack significant methods to reach positive recognition. Some of these methods are forensic facial reconstruction, superimposition, and DNA fingerprint analysis (Burns 2013), beside maintaining bony specimens of each human remains and keeping them for a long time.

\section{Conclusions}

This case report aims at raising the awareness among radiologists and radiology centers about their key role in personal identification and the importance of maintaining patients' radiographs for forensic purposes. It also indicates that even small bones such as the patellae and tiny abnormal features, such as the incisal edge fracture of a tooth, must be carefully scrutinized and documented in PM examination.

\section{Abbreviations}

AM: Ante-mortem; PM: Post-mortem

\section{Acknowledgements}

Not applicable.

\section{Authors' contributions}

The manuscript was carried out, written, and approved in collaboration with all authors.

\section{Funding}

This research did not receive any specific grant from funding agencies in the public, commercial, or not-for-profit sectors.

\section{Availability of data and materials}

All data generated or analyzed during this study are included in this published article and its supplementary information files.

\section{Ethics approval and consent to participate}

This study is legally authorized by the committee of ethics in al-Muwasat University Hospital (No. 386/2017).

\section{Consent for publication}

The consent for publication has been taken from the victim's brother.

\section{Competing interests}

The authors declare that they have no competing interests.

\section{Author details}

${ }^{1}$ Department of Oral Medicine, Faculty of Dentistry, Damascus University, Damascus, Syria. ${ }^{2}$ Department of Oral Histology and Pathology, Faculty of Dentistry, Damascus University, Damascus, Syria. ${ }^{3}$ Department of Forensic Medicine, Ministry of Health, Damascus, Syria. ${ }^{4}$ Faculty of Medicine,

Damascus University, Damascus, Syria. ${ }^{5}$ Department of Forensic Medicine,

Faculty of Medicine, Damascus University, Damascus, Syria.

Received: 27 January 2020 Accepted: 23 August 2020

Published online: 01 September 2020

\section{References}

Burns KR (2013) Forensic anthropology training manual. Pearson Education, Inc. Upper Saddle River

DiMaio VJM (1999) Gunshot wounds: practical aspects of firearms, ballistics, and forensic techniques. CRC Press LLC., Boca Raton

Dumanèiæ J, Kaiæ Z, Njemirovskij V, Brkiæ H, Zeèeviæ D (2001) Dental identification after two mass disasters in Croatia. Croat Med J 42(6):657-662

Fierro G, Calvino G, Sasso F (1987) Congenital double patella. Presentation of a case. Radiol Med 73(1-2):113-115

Franco A, Willems G, Souza PHC, Bekkering GE, Thevissen P (2015) The uniqueness of the human dentition as forensic evidence: a systematic review on the technological methodology. Int J Legal Med 129(6):1277-1283. https://doi.org/10.1007/s00414-014-1109-7

Işcan MY, Loth SR, Wright RK (1984) Age estimation from the rib by phase analysis: white males. J Forensic Sci 29(4):1094-1104

Kullman $L$ (2002) Case report on the identification of a murder victim by forensic dental techniques. Saudi Dental J 14002

Lamendin H, Baccino E, Humbert JF, Tavernier JC, Nossintchouk RM, Zerilli A (1992) A simple technique for age estimation in adult corpses: the two criteria dental method. J Forensic Sci 37(5):1373-1379

Ma J, Shi F, Huang C, Gu S (2017) Forensic Identification of Bipartite Patella Misdiagnosed as Patella Fracture. J Forensic Sci 62(4):1089-1091. https://doi. org/10.1111/1556-4029.13357

Miranda GE, de Freitas SG, de Abreu Maia LV, Melani RFH (2016) An unusual method of forensic human identification: use of selfie photographs. Forensic Sci Int 263:e14-e17. https://doi.org/10.1016/j.forsciint.2016.04.028

Ortner DJ (2003) Identification of pathological conditions in human skeletal remains. Academic Press, San Diego

Riddick L, Brogdon B, Lasswell-Hoff J, Delmas B (1983) Radiographic identification of charred human remains through use of the dorsal defect of the patella. J Forensic Sci 28(1):263-267. https://doi.org/10.1520/JFS12261J 
Silva R, Franco A, Dias P, Gonçalves A, Paranhos L (2013) Interrelationship between forensic radiology and forensic odontology - A case report of identified skeletal remains. J Forensic Radiol Imag 1(4):201-206. https://doi. org/10.1016/i.jofri.2013.06.005

Silva R, Pereira S, Prado F, Daruge E, Daruge E (2008) Forensic odontology identification using smile photograph analysis-case reports. J Forensic Odontostomatol 26(1):12-17

Silva RF, Franco A, de Souza JB, Picoli FF, Mendes SDSC, Nunes FG (2015) Human identification through the analysis of smile photographs. Am J Forensic Med Pathol 36(2):71-74. https://doi.org/10.1097/PAF.0000000000000148

Silva RF, Franco A, Mendes SDSC, Picoli FF, de Azevedo Marinho DE (2014) Human identification through the patella-report of two cases. Forensic Sci Int 238:e11-e14. https://doi.org/10.1016/j.forsciint.2014.02.025

Silva RF, Franco A, Seixas JR, Oliveira W, Picoli FF (2016) Positive identification of a decomposed human body through forensic anthropology and smile photographs: A case report. Eur J Forensic Sci 3(4):1-4. https://doi.org/10. 5455/ejfs.205494

Terada ASSD, Leite NLP, Silveira TCP, Secchieri JM, Guimarães MA, Silva RHAd (2013) Human identification in forensic dentistry from a photographic record of smile: a case report. Rev Odontol UNESP 40(4):199-202

Tinoco R, Martins E, Daruge E Jr, Daruge E, Prado F, Caria P (2010) Dental anomalies and their value in human identification: a case report. J Forensic Odontostomatol 28(1):39-43

Trotter M, Gleser GC (1952) Estimation of stature from long bones of American Whites and Negroes. Am J Phys Anthropol 10(4):463-514. https://doi.org/10. 1002/ajpa.1330100407

Ying C, Wang Y, Wan L (2010) Imaging manifestation and medicolegal significance of bipartite patella. Fa yi xue za zhi 26(1):43-46

\section{Publisher's Note}

Springer Nature remains neutral with regard to jurisdictional claims in published maps and institutional affiliations.

\section{Submit your manuscript to a SpringerOpen ${ }^{\circ}$ journal and benefit from:}

- Convenient online submission

- Rigorous peer review

- Open access: articles freely available online

High visibility within the field

- Retaining the copyright to your article

Submit your next manuscript at $\boldsymbol{\nabla}$ springeropen.com 